\title{
The Impact of Inflation on the Medical and Hospital Money Transfers of the Neurosurgical Procedures of the Brazilian Unified Healthcare System from 2008 to 2017
}

\section{O Impacto da inflação nos repasses médicos e hospitalares dos procedimentos neurocirúrgicos do Sistema Único de Saúde durante o período de 2008 a 2017}

\author{
Marcelo José Silva de Magalhães ${ }^{1,2,30}$ Graciella Lopes Araújo ${ }^{2}$ Letícia Pinheiro de Almeida ${ }^{2}$ \\ Wanessa Santos Soares ${ }^{2}$ Daniel Santos Martins ${ }^{2}$ Guilherme Duraes Martins ${ }^{2}$ \\ Isadora Fonseca de Vasconcelos ${ }^{2}$ Lara Cristina Lima Delgado ${ }^{2}$ Henrique Nunes Pereira Oliva ${ }^{3}$ \\ Aline Almeida de Magalhães ${ }^{3}$
}

${ }^{1}$ Hospital Vila da Serra, Belo Horizonte, Hospital Aroldo Tourinho, Montes Claros, MG, Brazil

2 Faculdades Unidas do Norte de Minas (FUNORTE), Montes Claros, MG, Brazil

${ }^{3}$ Faculdades Integradas de Montes Claros (FIPMoc), Montes Claros, MG, Brazil

Arq Bras Neurocir 2020;39(4):249-255.
Address for correspondence Marcelo José Silva de Magalhães, MD, MSc, Rua Francisco Versiane Ataide, 760, apartamento 1301., Montes Claros, MG, 39401-039, Brazil (e-mail: marcelo7779@yahoo.com.br).

\begin{abstract}
Keywords

- neurosurgery

- inflation

- medical fees

- hospital costs

Introduction There are more than 1,500 hospital procedures included in the Brazilian Unified Healthcare System's (SUS, in the Portuguese acronym) table, which is the reference for service payment provided by establishments serving the public health network, and they are stagnant. The underfinancing of procedures is so dramatic that in some cases the amounts paid by the SUS are even lower than the taxes generated by the costs of the same procedures in Brazilian private hospitals. This article aims to compare the evolution of the compensation of neurosurgical procedures by calculating the percentile of the lag in the values transferred to both neurosurgeons and hospitals, according to the SUS table, establishing the ideal and real values according to the current inflation, in a retrospective 9-year comparison.

Methodology This is an observational, comparative, retrospective study, based on the values of medical and hospital money transfers of 25 neurosurgical procedures in 2008, which were corrected according to the 2017 National Consumer Price Index (IPCA, in the Portuguese acronym).

Results Through this study, from 2008 to 2017, the transfers of medical fees regarding neurosurgical techniques are almost completely outdated. As examples, we can mention: the external/subgaleal ventricular shunt, with a deficit of $43.6 \%$; the
\end{abstract}

received

February 2, 2017

accepted

April 24, 2017
DOI https://doi.org/

10.1055/s-0038-1657764. ISSN 0103-5355.
Copyright $\odot 2020$ by Thieme Revinter

Publicações Ltda, Rio de Janeiro, Brazil
License terms

c) $(1) \$$ 
electrode implant for brain stimulation, with - $41.67 \%$; and decompressive craniotomy, with $-32.21 \%$ in relation to the corrected value. Only 4 of the 25 neurosurgeries present a value above that predicted by the IPCA, one of them being cerebral aneurysm embolization larger than $1.5 \mathrm{~cm}$ with a narrow neck (+8.0\%). Regarding the money transfers to hospitals, all procedures are $43.6 \%$ lower than expected, since there was no readjustment in the amounts paid to the institutions in the analyzed period. For example, in 2008, for the transposition of the cubital nerve, $R \$ 267.30$ were transferred, and the same amount was maintained in 2017; and, for the surgical treatment of compressive syndrome in osteofibrous tunnel at carpal level ( $R \$ 145.18)$, the amount also remained fixed throughout these 9 years.

Conclusion Because they did not follow the evolution of the economy, in $80 \%$ of the surgeries, the neurosurgeons did not have their economic demands met regarding the procedures performed through SUS. And the data became even more alarming when the money transfers to hospitals were evaluated, since there was no evolution in the money transfers for any of the neurosurgeries evaluated.

\section{Resumo}

\section{Palavras-chave}

- neurocirurgia

- inflação

- honorários médicos

- custos hospitalares
Introdução Mais de 1.500 procedimentos hospitalares incluídos na tabela do Sistema Único de Saúde (SUS) - considerada padrão de referência para pagamento dos serviços prestados por estabelecimentos que atendem à rede pública da saúde-estão estagnados. O subfinanciamento dos procedimentos é tão dramático que, em alguns casos, os valores pagos pelo SUS ficam abaixo até mesmo dos impostos gerados pelos custos dos mesmos procedimentos realizados nos hospitais particulares com fins lucrativos. Por meio deste artigo, objetiva-se, portanto, comparar a evolução da remuneração dos procedimentos neurocirúrgicos, calculando a porcentagem de defasagem dos valores repassados tanto aos neurocirurgiões quanto aos hospitais, segundo a tabela SUS, estabelecendo os valores ideais e reais de acordo com a inflação vigente, em um comparativo retrospectivo de 9 anos.

Metodologia Trata-se de um estudo do tipo observacional, comparativo-retrospectivo, baseado em valores do repasse médico e hospitalar de 25 procedimentos neurocirúrgicos em 2008, corrigidos conforme o valor do Índice Nacional de Preços ao Consumidor Amplo (IPCA) de 2017.

Resultados Por meio deste estudo, percebeu-se que de 2008 até 2017, os repasses dos honorários médicos referentes às técnicas neurocirúrgicas encontravam-se, quase em sua totalidade, desatualizados. Como exemplo, podem ser citados: a derivação ventricular externa/subgaleal, com déficit de 43,6\%; o implante de eletrodo para estimulação cerebral, com - 41,67\%; e a craniotomia descompressiva, com - 32,21\% em relação ao valor corrigido. Apenas 4 das 25 neurocirurgias encontravam-se com valor acima do previsto pelo IPCA, entre as quais encontrava-se a embolização de aneurisma cerebral maior do que $1,5 \mathrm{~cm}$ com colo estreito $(+8,0 \%)$. No que tange ao repasse hospitalar, todos os procedimentos estavam $43,6 \%$ abaixo do esperado, uma vez que não houve reajuste dos valores pagos às instituições no período analisado. Repassavase, em 2008 , o valor de $R \$ 267,30$ pelo procedimento de transposição do nervo cubital, por exemplo. A mesma quantia foi mantida em 2017. O mesmo ocorreu com o valor pago pelo tratamento cirúrgico da síndrome compressiva em túnel osteofibroso no nível do carpo ( $R \$ 145,18)$, que também se manteve fixo ao longo desses 9 anos.

Conclusão Por não terem acompanhado a evolução da economia, em mais de $80 \%$ das cirurgias, os neurocirurgiões não tiveram suas demandas econômicas atendidas quanto aos procedimentos realizados pelo SUS. E os dados se tornam ainda mais alarmantes quando avaliado o repasse hospitalar, pois não houve evolução nos repasses para nenhuma das neurocirurgias avaliadas. 


\section{Introduction}

The Unified Health System (SUS, in the Portuguese acronym) table, considered a reference for service payment provided by affiliated and philanthropic establishments that serve the public health network, maintains the values of more than 1,500 surgical procedures. ${ }^{1}$

$>$ Medical conditions requiring surgical procedures represent more than $10 \%$ of the total number of affections in the world. Due to the more restricted access to health, the cases already arrive with a higher degree of complexity. Subspecialty procedures, such as those of neurosurgery, represent a major impact on the economy. In addition to the direct cost of these procedures, it is considered that the more invasive and delicate, the more expensive they become, requiring longer hospitalization, and generating more hospital costs. ${ }^{2}$

Despite the financial sustainability in the health sector being foreseen in the law n. 8.080/90, which explains the need for a balance between the remuneration of the SUS service providers and the contracting establishment, there is great risk in surgical practice. Over the years, treatment costs have increased due to equipment modernization, emergence of new techniques and medications, as well as the discovery of new illnesses. The scarcity of resources has made the management of these costs increasingly complex, requiring a difficult choice about which sector of the institution needs more investment application. In addition, hospitals fail to make an exact estimate of their expenditures, since they do not have a permanent control of these, which increases the risk of financial collapse of these entities. ${ }^{3,4}$

In this way, even if there is a table with fixed transfer values (SUS table), such values will hardly cover the actual costs of each procedure, since, in addition to the direct cost, there are countless and unpredictable complications that require longer hospitalization and, consequently, more resources. ${ }^{3,4}$

Inflation, a generalized and universal phenomenon, is defined as the simultaneous increase in the prices of various goods or services, in a certain region, in a certain period, which results in currency devaluation. ${ }^{5}$

This, therefore, was the parameter used by this article as basis for calculating the increase in the remuneration of neurosurgeons and the effective hospital transfer through SUS financed procedures. Through the comparison between the same variables, in an interval of 9 years, the discrepancies between the ideal and real values were measured.

With the present study, we aimed to: calculate the percentage of lag in the SUS table of 24 neurosurgical procedures considering a period of 9 years, through the national index of wide consumer prices (IPCA, in the Portuguese acronym), official inflation index in Brazil; establish the ideal and real values of financial transfers to institutions and medical professionals, according to the impact of the current inflation; calculate neurosurgeon remuneration considering the basic salary in the corresponding period, and comparing the data obtained in the years 2008 to 2017, to evaluate the purchasing power with the medical salary.

\section{Methodology}

A descriptive, comparative and retrospective research was performed, based on the values of the neurosurgery procedures in 2008 corrected according to the 2017 IPCA, from the citizen's calculator of the Central Bank of Brazil. The most commonly used codes from each surgery subgroup were considered. The IPCA was considered to calculate the impact of inflation on the surgical codes during the study period. We chose the IPCA because it is an index that covers families living in urban areas with monthly incomes comprised between 1 and 40 minimum wages-whatever the source of income. For IPCA calculation, the software used was the online citizen's calculator platform, from the Brazilian Central Bank. Through this software, it was possible to post the value to be corrected and to specify the time interval and the index to be used for correcting the values in Reais. The search sites SciELO and Bireme were used as a source of research for the choice of scientific articles, associating the terms neurosurgery; inflation; medical fees; SUS neurosurgery medical fees; inflation; and health. We sought to select articles with available text, with researches conducted in humans, in English, Portuguese, and Spanish. Articles published in languages other than English, Portuguese, and Spanish were excluded. After application of the appropriate research filters, the articles were selected by title and abstract, for later integral analysis. Those who did not meet the criteria were excluded. The databases of the Government (department of informatics of the SUS, [Datasus, in the Portuguese acronym], the Brazilian Institute of Geography and Statistics (IBGE, in the Portuguese acronym), the Diário Oficial da União (which is the official journal of the federal government of Brazil), the citizen's calculator platform, the Central Bank of Brazil and the Federal Council of Medicine website were used. ${ }^{1,6-9}$

\section{Results}

Based on the data collected in the SUS table, analyses were performed to check the readjustment of the values passed on to both neurosurgeons and hospitals, considering the inflation variation in the studied period (2008-2017). It was an analysis of the evolution of medical fees and the financing of institutions in this 9-year period (-Table $\mathbf{1}$ ).

Analyzing -Table 1, it is noted that the lowest medical onlendings in 2017 were: cranial trepanation (R\$ 107.52); surgical treatment of compressive syndrome in osteofibrous tunnel at the carpal level ( $R \$ 202.44$ ); transposition of the cubital nerve ( $R$ \$247.95); subgaleal external ventricular shunt ( $\mathrm{R} \$ 286.00)$; anterior cervical discectomy (1 level) ( $\mathrm{R} \$ 380.00$ ); and decompressive craniotomy ( $\mathrm{R} \$ 391.86$ ). Among the procedures with greater transfer, we highlight microsurgery for aneurysm of the anterior cerebral circulation lower than $1.5 \mathrm{~cm}(\mathrm{R} \$ 2,054.08)$, and microsurgery for intracranial tumor ( $R \$ 1,568.00)$. In terms of greater lag caused by inflation, the following procedures are provided: peritoneal external ventricular shunt/atrium/pleura/raqui; Subgaleal external ventricular 
Table 1 Physicians' fees in 24 Unified Health System neurosurgical codes of 2008 and 2017, and calculation of the corrected value according to the National Consumer Price Index

\begin{tabular}{|c|c|c|c|c|}
\hline Procedures & $\begin{array}{l}\text { Medical } \\
\text { Fees } 2008\end{array}$ & $\begin{array}{l}\text { Real Medical } \\
\text { Fees } 2017\end{array}$ & $\begin{array}{l}\text { Corrected } \\
\text { Medical } \\
\text { Fees } 2017\end{array}$ & $\begin{array}{l}\text { Difference } \\
\text { between } \\
\text { fees (\%) }\end{array}$ \\
\hline $\begin{array}{l}\text { Posterior thoracolumbosacral arthrodesis } \\
\text { ( } 2 \text { levels; includes instrumentation) }\end{array}$ & $R \$ 1,155.78$ & $R \$ 1,155.78$ & $R \$ 2,049.51$ & $-43.6 \%$ \\
\hline Decompressive craniotomy & $\mathrm{R} \$ 261.24$ & $\mathrm{R} \$ 391.86$ & $\mathrm{R} \$ 578.07$ & $-32.21 \%$ \\
\hline Peritoneum/atrium/pleura/raqui external ventricular shunt & $\mathrm{R} \$ 454.72$ & $\mathrm{R} \$ 682.08$ & $R \$ 1,209.51$ & $-43.6 \%$ \\
\hline Subgaleal external ventricular shunt & $R \$ 220.64$ & $\mathrm{R} \$ 286.00$ & $\mathrm{R} \$ 507.16$ & $-43.6 \%$ \\
\hline Anterior cervical discectomy (up to 2 levels with microscope) & $\mathrm{R} \$ 470.00$ & $\mathrm{R} \$ 470.00$ & $\mathrm{R} \$ 833.44$ & $-43.6 \%$ \\
\hline Anterior cervical discectomy (1 level) & $\mathrm{R} \$ 380.00$ & $\mathrm{R} \$ 380.00$ & $\mathrm{R} \$ 673.84$ & $-43.6 \%$ \\
\hline $\begin{array}{l}\text { Posterior cervical/lumbar/loin-sacral discectomy } \\
\text { (1 level with microscope) }\end{array}$ & $\mathrm{R} \$ 470.00$ & $\mathrm{R} \$ 470.00$ & $\mathrm{R} \$ 833.44$ & $-43.6 \%$ \\
\hline $\begin{array}{l}\text { Posterior cervical/lumbar/loin-sacral discectomy } \\
\text { ( } 2 \text { or more levels with a microscope) }\end{array}$ & $R \$ 533,52$ & $R \$ 456,00$ & $\mathrm{R} \$ 808,61$ & $-43.6 \%$ \\
\hline $\begin{array}{l}\text { Cerebral aneurysm embolization greater than } \\
15 \mathrm{~mm} \text { with narrow neck }\end{array}$ & $\mathrm{R} \$ 448.00$ & $\mathrm{R} \$ 858.00$ & $\mathrm{R} \$ 794.43$ & $+8.0 \%$ \\
\hline Electrode implant for cerebral stimulation & $\mathrm{R} \$ 933.34$ & $\mathrm{R} \$ 965.25$ & $\mathrm{R} \$ 1.655 .07$ & $-41.67 \%$ \\
\hline Intrathecal implant of drug infusion pump & $\mathrm{R} \$ 597.18$ & $\mathrm{R} \$ 607.75$ & $\mathrm{R} \$ 1,058.96$ & $-42.6 \%$ \\
\hline Endoscopic cerebral microsurgery & $\mathrm{R} \$ 932.96$ & $\mathrm{R} \$ 1,399.44$ & $R \$ 1,654.39$ & $-15.41 \%$ \\
\hline Medullary tumor microsurgery & $\mathrm{R} \$ 694.40$ & $\mathrm{R} \$ 1,041.60$ & $R \$ 1,231.36$ & $-15.41 \%$ \\
\hline $\begin{array}{l}\text { Microsurgery for anterior cerebral circulation } \\
\text { aneurysm smaller than } 1.5 \mathrm{~cm}\end{array}$ & $\mathrm{R} \$ 784.00$ & $R \$ 2,054.08$ & $\mathrm{R} \$ 1,140.86$ & $+80.0 \%$ \\
\hline Microsurgery for arteriovenous malformation & $\mathrm{R} \$ 604.80$ & $\mathrm{R} \$ 1,209.60$ & $\mathrm{R} \$ 868.91$ & $+39.2 \%$ \\
\hline Microsurgery for intracranial tumor & $\mathrm{R} \$ 784.00$ & $R \$ 1,568.00$ & $\mathrm{R} \$ 1,390.25$ & $+12.78 \%$ \\
\hline Craniofacial reconstruction & $\mathrm{R} \$ 447.96$ & $R \$ 671.94$ & $\mathrm{R} \$ 794.36$ & $-15.41 \%$ \\
\hline Transposition of the cubital nerve & $\mathrm{R} \$ 165.30$ & $\mathrm{R} \$ 247.95$ & $\mathrm{R} \$ 293.12$ & $-15.41 \%$ \\
\hline Surgical treatment of extradural hematoma & $\mathrm{R} \$ 454.72$ & $\mathrm{R} \$ 682.08$ & $\mathrm{R} \$ 806.34$ & $-15.41 \%$ \\
\hline Surgical treatment of intracerebral hematoma & $\mathrm{R} \$ 325.99$ & $R \$ 488.99$ & $\mathrm{R} \$ 867.11$ & $-43.6 \%$ \\
\hline Surgical treatment of acute subdural hematoma & $\mathrm{R} \$ 454.72$ & $\mathrm{R} \$ 682.08$ & $\mathrm{R} \$ 806.34$ & $-15.41 \%$ \\
\hline $\begin{array}{l}\text { Surgical treatment of compressive syndrome } \\
\text { in osteofibrous tunnel at carpal level }\end{array}$ & $\mathrm{R} \$ 134.96$ & $R \$ 202.44$ & $R \$ 239.32$ & $-15.41 \%$ \\
\hline Surgical treatment for open dysraphism & $\mathrm{R} \$ 322.56$ & $\mathrm{R} \$ 483.84$ & $\mathrm{R} \$ 571.99$ & $-15.41 \%$ \\
\hline Cranial trepanation & $\mathrm{R} \$ 71.68$ & $\mathrm{R} \$ 107.52$ & $\mathrm{R} \$ 127.11$ & $-15.41 \%$ \\
\hline
\end{tabular}

shunt; and cervical discectomy by the anterior pathway ( 1 level), with a rate of $-43.6 \%$ in the analyzed period.

If there had been proper correction of the values according to inflation in 2017, it would have: peritoneum/atrium/pleura/ raqui external ventricular shunt passing from $R \$ 682.08$ to $R \$$ 1,209.51; Subgaleal external ventricular shunt passing from $R \$$ 286.00 to $\mathrm{R} \$ 507,16$; and cervical discectomy by anterior pathway (1 level), from $\mathrm{R} \$ 380.00$ to $\mathrm{R} \$ 673.84$.

Only 4 of the 25 procedures analyzed were readjusted above inflation: embolization of cerebral aneurysm greater than $1.5 \mathrm{~cm}$ with a narrow neck ( $\mathrm{R} \$ 858.00 ;+8.0 \%)$; microsurgery for intracranial tumor ( $\mathrm{R} \$ 1,568.00 ;+12.78 \%)$; microsurgery for arteriovenous malformation ( $\mathrm{R} \$ 1,209.60 ;+39.2 \%$ ), and microsurgery for aneurysm of the anterior cerebral circulation lower than $1.5 \mathrm{~cm}(\mathrm{R} \$ 2,054.08 ;+80.0 \%)$.
The mean value passed on to neurosurgeons regarding the 24 neurosurgical procedures evaluated in 2008 was approximately $\mathrm{R} \$ 504.26$ per procedure. This means that, in 2017, the amount was $\mathrm{R} \$ 731.74$, and if inflation had been considered in the course of these 9 years, this value should have been $\mathrm{R} \$$ 908.06. Thus, we find a mean impairment of $\mathrm{R} \$$ 176.30 per performed surgery.

In the hospital context, the lowest onlendings were related to: the surgical treatment of the compressive syndrome in the osteofibrous tunnel at the carpal level ( $R \$ 145.18$ ); the transposition of the cubital nerve ( $\mathrm{R} \$ 267.30$ ); the decompressive craniotomy ( $\mathrm{R} \$ 415.89$ ); and cranial trepanation ( $\mathrm{R} \$ 494.83$ ).

The procedures with best onlendings were: microsurgery for arteriovenous malformation ( $\mathrm{R} \$ 1,698.05$ ); posterior thoracolumbosacral arthrodesis in 2 levels, including 
Table 2 Transfer of hospital values of the 24 neurosurgical procedures (2008 and 2017) and calculation of corrected values according to the National Consumer Price Index

\begin{tabular}{|c|c|c|c|}
\hline Neurosurgical procedures & $\begin{array}{l}\text { Hospital } \\
\text { budget } 2008\end{array}$ & $\begin{array}{l}\text { Hospital } \\
\text { budget } 2017\end{array}$ & $\begin{array}{l}\text { Corrected hospital } \\
\text { budget } 2017\end{array}$ \\
\hline $\begin{array}{l}\text { Posterior thoracolumbosacral arthrodesis } \\
\text { ( } 2 \text { levels; includes instrumentation) }\end{array}$ & $R \$ 1,625.92$ & $R \$ 1,625.92$ & $\mathrm{R} \$ 2,883.20$ \\
\hline Decompressive craniotomy & $R \$ 415.89$ & $\mathrm{R} \$ 415.89$ & $\mathrm{R} \$ 737.40$ \\
\hline Peritoneum/atrium/pleura/raqui external ventricular shunt & $\mathrm{R} \$ 818.64$ & $\mathrm{R} \$ 818.64$ & $\mathrm{R} \$ 1,451.67$ \\
\hline Subgaleal external ventricular shunt & $R \$ 799.64$ & $R \$ 799.64$ & $\mathrm{R} \$ 1,417.98$ \\
\hline Anterior cervical discectomy (up to 2 levels with microscope) & $\mathrm{R} \$ 1,250.27$ & $\mathrm{R} \$ 1,250.27$ & $\mathrm{R} \$ 2,217.07$ \\
\hline Anterior cervical discectomy (1 level) & $R \$ 963.00$ & $\mathrm{R} \$ 963.00$ & $\mathrm{R} \$ 1,707.66$ \\
\hline $\begin{array}{l}\text { Posterior cervical/lumbar/loin-sacral discectomy } \\
\text { (1 level with microscope) }\end{array}$ & $\mathrm{R} \$ 1,250.27$ & $\mathrm{R} \$ 1,250.27$ & $\mathrm{R} \$ 2,217.07$ \\
\hline $\begin{array}{l}\text { Posterior cervical/lumbar/loin-sacral discectomy } \\
\text { (2 or more levels with a microscope) }\end{array}$ & $\mathrm{R} \$ 1,252.40$ & $\mathrm{R} \$ 1,252.40$ & $\mathrm{R} \$ 2,220.70$ \\
\hline $\begin{array}{l}\text { Cerebral aneurysm embolization greater than } \\
15 \mathrm{~mm} \text { with narrow neck }\end{array}$ & $\mathrm{R} \$ 1,238.88$ & $\mathrm{R} \$ 1,238.88$ & $\mathrm{R} \$ 2,196.87$ \\
\hline Electrode implant for cerebral stimulation & $\mathrm{R} \$ 1,023.06$ & $\mathrm{R} \$ 1,023.06$ & $\mathrm{R} \$ 1,814.16$ \\
\hline Intrathecal implant of drug infusion pump & $R \$ 720.66$ & $R \$ 720.66$ & $\mathrm{R} \$ 1,277.93$ \\
\hline Endoscopic cerebral microsurgery & $\mathrm{R} \$ 1,770.17$ & $\mathrm{R} \$ 1,770.17$ & $\mathrm{R} \$ 3,138.99$ \\
\hline Medullary tumor microsurgery & $\mathrm{R} \$ 1,603.32$ & $\mathrm{R} \$ 1,603.32$ & $\mathrm{R} \$ 2,843.12$ \\
\hline $\begin{array}{l}\text { Microsurgery for anterior cerebral circulation } \\
\text { aneurysm smaller than } 1.5 \mathrm{~cm}\end{array}$ & $\mathrm{R} \$ 1,591.63$ & $\mathrm{R} \$ 1,591.63$ & $\mathrm{R} \$ 2,822.39$ \\
\hline Microsurgery for arteriovenous malformation & $\mathrm{R} \$ 1,698.05$ & $\mathrm{R} \$ 1,698.05$ & $\mathrm{R} \$ 3,011.11$ \\
\hline Microsurgery for intracranial tumor & $\mathrm{R} \$ 1,591.63$ & $\mathrm{R} \$ 1,591.63$ & $\mathrm{R} \$ 2,822.39$ \\
\hline Craniofacial reconstruction & $\mathrm{R} \$ 1,346.57$ & $\mathrm{R} \$ 1,346.57$ & $\mathrm{R} \$ 2,387.84$ \\
\hline Transposition of the cubital nerve & $R \$ 267.30$ & $R \$ 267.30$ & $\mathrm{R} \$ 474.00$ \\
\hline Surgical treatment of extradural hematoma & $\mathrm{R} \$ 816.64$ & $\mathrm{R} \$ 816.64$ & $\mathrm{R} \$ 1,448.13$ \\
\hline Surgical treatment of intracerebral hematoma & $\mathrm{R} \$ 821.20$ & $\mathrm{R} \$ 821.20$ & $\mathrm{R} \$ 1,456.21$ \\
\hline Surgical treatment of acute subdural hematoma & $\mathrm{R} \$ 818.64$ & $\mathrm{R} \$ 818.64$ & $\mathrm{R} \$ 1,451.67$ \\
\hline $\begin{array}{l}\text { Surgical treatment of compressive syndrome } \\
\text { in osteofibrous tunnel at carpal level }\end{array}$ & $\mathrm{R} \$ 145.18$ & $\mathrm{R} \$ 145.18$ & $\mathrm{R} \$ 257.44$ \\
\hline Surgical treatment for open dysraphism & $R \$ 859.28$ & $R \$ 859.28$ & $\mathrm{R} \$ 1,523.74$ \\
\hline Cranial trepanation & $\mathrm{R} \$ 494.83$ & $\mathrm{R} \$ 494.83$ & $\mathrm{R} \$ 877.47$ \\
\hline
\end{tabular}

instrumentation ( $\mathrm{R} \$ 1$ 1,625.92); and spinal cord tumor microsurgery ( $\mathrm{R} \$ 1,603.32)$.

It was found that there was a lag of $43.6 \%$ in the values passed to the hospitals during the studied period, according to the IPCA. There was no kind of readjustment in the values of the onlendings to the institutions during the period analyzed. The mean of the values passed in this period was $\mathrm{R} \$ 1,049.29$, and the corrected mean would be $\mathrm{R} \$ 1,860.87$, that is, there was a $\mathrm{R} \$ 811.58$ difference (-Table $\mathbf{2}$ ).
After the conversion of the values of each procedure into minimum wages in the years 2008 and 2017, it was observed that the value of the transfer to the neurosurgeons regarding all procedures (except microsurgery for aneurysm of the anterior cerebral circulation less than $1.5 \mathrm{~cm}$ ) did not follow the proportion of increase in the minimum wage in the past 9 years ( - Table 3 ). During the period 2008 to 2017 , the minimum wage presented a correction of $125.78 \%$

Table 3 Conversion of the transfer value of the neurosurgical code in minimum wages in the years 2008 and $2017(100 \%=1$ minimum wage for the respective year)

\begin{tabular}{|l|l|l|}
\hline Neurosurgical procedures & Salary compromise 2008 (\%)* & Salary compromise 2017 (\%) $^{* *}$ \\
\hline $\begin{array}{l}\text { Posterior thoracolumbosacral arthrodesis } \\
(2 \text { levels; includes instrumentation) }\end{array}$ & $278.5 \%$ & $173.52 \%$ \\
\hline
\end{tabular}


Table 3 (Continued)

\begin{tabular}{|l|l|l|}
\hline Neurosurgical procedures & Salary compromise 2008 (\%) & Salary compromise 2017 (\%)** \\
\hline Decompressive craniotomy & $62.94 \%$ & $41.82 \%$ \\
\hline $\begin{array}{l}\text { Peritoneum/atrium/pleura/raqui external } \\
\text { ventricular shunt }\end{array}$ & $109.57 \%$ & $72.79 \%$ \\
\hline Subgaleal external ventricular shunt & $53.16 \%$ & $30.52 \%$ \\
\hline $\begin{array}{l}\text { Anterior cervical discectomy } \\
\text { (up to 2 levels with microscope) }\end{array}$ & $113.25 \%$ & $50.16 \%$ \\
\hline Anterior cervical discectomy (1 level) & $91.56 \%$ & $40.55 \%$ \\
\hline $\begin{array}{l}\text { Posterior cervical/lumbar/loin-sacral discectomy } \\
\text { (1 level with microscope) }\end{array}$ & $113.25 \%$ & $50.16 \%$ \\
\hline $\begin{array}{l}\text { Posterior cervical/lumbar/loin-sacral discectomy } \\
\text { (2 or more levels with a microscope) }\end{array}$ & $128.55 \%$ & $48.66 \%$ \\
\hline $\begin{array}{l}\text { Cerebral aneurysm embolization greater than } \\
15 \text { mm with narrow neck }\end{array}$ & $107.95 \%$ & $91.56 \%$ \\
\hline Electrode implant for cerebral stimulation & $224.9 \%$ & $103.1 \%$ \\
\hline Intrathecal implant of drug infusion pump & $143.89 \%$ & $64.86 \%$ \\
\hline Endoscopic cerebral microsurgery & $224.8 \%$ & $149.35 \%$ \\
\hline Medullary tumor microsurgery & $167.32 \%$ & $111.16 \%$ \\
\hline $\begin{array}{l}\text { Microsurgery for anterior cerebral circulation } \\
\text { aneurysm smaller than 1.5 cm }\end{array}$ & $188.91 \%$ & $219.21 \%$ \\
\hline Microsurgery for arteriovenous malformation & $145.73 \%$ & $129.09 \%$ \\
\hline Microsurgery for intracranial tumor & $188.91 \%$ & $167.34 \%$ \\
\hline Craniofacial reconstruction & $107.94 \%$ & $71.71 \%$ \\
\hline Transposition of the cubital nerve & $39.83 \%$ & $26.46 \%$ \\
\hline Surgical treatment of extradural hematoma & $109.57 \%$ & $72.79 \%$ \\
\hline Surgical treatment of intracerebral hematoma & $78.55 \%$ & $52.18 \%$ \\
\hline Surgical treatment of acute subdural hematoma & $109.57 \%$ & $72.79 \%$ \\
\hline $\begin{array}{l}\text { Surgical treatment of compressive syndrome } \\
\text { in Osteofibrous tunnel at carpal level }\end{array}$ & $35.52 \%$ & $21.6 \%$ \\
\hline Surgical treatment for open dysraphism & $72.72 \%$ & $51.63 \%$ \\
\hline Cranial trepanation & $17.27 \%$ & $11.47 \%$ \\
\hline
\end{tabular}

\section{Discussion}

The present study evidences the lag of medical fees related to the procedures, in almost its totality. An example is the external/subgaleal ventricular shunt, with a deficit of $43.6 \%$ in its value. It was found that few neurosurgeries received a value above that predicted by IPCA, and one of them was the embolization of cerebral aneurysm greater than $1.5 \mathrm{~cm}$ with a narrow neck $(+8 \%)$. The mismatch of the values becomes even more inconsistent when the calculation of the accumulated inflation in the past 9 years, according to IPCA, reaches almost $78 \% .^{8}$

Apparently, health professionals are exposed to mismatch of salary adjustments in relation to the current inflation, even internationally. According to a study performed by Perri et al on the wage transfer to vascular surgeons in the United
States between 2010 and 2015, there was a 20.9\% decrease in medical transfer, while the hospital equivalent decreased 6.6\%. Due to the health system in the United States being different from the Brazilian one, the greater deficit fell on surgeons. ${ }^{10}$

Other variables can also be compared, such as the increase in the minimum wage in this time interval. In 2008 , the value was $R \$ 415.00$, while in 2017 the salary was $R \$ 937.00$. It is an increase of more than $125 \%$, while the average increase of the transfer to neurosurgeons by SUS financed procedures, according to the calculations in this article, was only $45 \%{ }^{11,12}$

Considering the increase of the Brazilian population in the past 10 years, according to the IBGE, in a census performed in 2007, the population was 183.9 million inhabitants. Today, it is estimated that the population is $\sim 208.4$ million 
inhabitants. It is possible to infer that, with the increase of almost $12 \%$ of the population, the demand of health services increased concomitantly. The investments in health, however, did not follow the growth and population demands, nor considered this impact on the SUS service providers, who had their work intensified in recent years, without, however, receiving the monetary equivalent. ${ }^{12}$

Given the complexity of the issue, it is certain that other variables are implicated in the process of increasing the expenditures of institutions in recent years, such as the salary of other employees (nursing, administration, safety, cleaning assistants, among others). An important point should also be emphasized, although not considered in the present study: the use of multiple surgery codes and sequential surgeries, when it is possible to use two or more codes for the same hospital admission guide with bigger transfer, consequently.

\section{Conclusion}

The inflation imposes undeniable impacts on society, dictating, in a blunt way, the remuneration, the values of taxes and the basic wages in all spheres of the economy. Unequivocally, the health area suffers the negative impacts of inflation, as it was proved in the present study. In 9 years, there were small adjustments in the values of some SUS procedures in the field of neurosurgery, and about more than $80 \%$ of the procedures surveyed were found to be stalled. This finding makes it true to assume that neurosurgeons, as well as the hospitals in which neurosurgeries are performed, do not have their economic demands attended regarding the surgical procedures performed by the SUS. Therefore, it is necessary to carry out more studies on this topic, to determine inflation's real impact on the cost of neurosurgical procedures and the remuneration of neurosurgeons in the field of private medicine, as well as studies covering other medical specialties.

Conflict of Interests

The authors have no conflict of interests to declare.

\section{References}

1 Conselho Federal de Medicina [homepage na internet]. Repasses federais: Estudo do CFM mostra que procedimentos hospitalares são prejudicados pela defasagem na Tabela SUS [acesso em 05 de setembro de 2017]. Disponível: https://www.cremesp.org.br

2 Abdelgadir J, Tran T, Muhindo A, et al. Estimating the cost of neurosurgical procedures in a low income detting: an observational economic analysis. World Neurosurg 2017;101:651-657. Doi: 10.1016/j.wneu.2017.02.048

3 Kos SR, Palermo NS, Klein L, Scarpin JE Repasse do SUS vs custo dos procedimentos hospitalares: é possível cobrir os custos com o repasse do SUS? In: Anais do XXII Congresso Brasileiro de Custos; 2015 nov 11-13;Foz do Iguaçu, Paraná. São Leopoldo: Associação Brasileira de Custos; 2016:1-16

4 Abreu CSP. Análise do custo de internação dos pacientes com AIDS, em um hospital de média complexidade em Porto Alegre, RS. São Leopoldo. Dissertação [Mestrado em Saúde Coletiva] - Universidade do Vale do Rio dos Sinos;2009

5 Rodrigues CH, Santos AC, Rodrigues IJF, Lourenço BS, Ribeiro FR. Inflação: um estudo de seus efeitos no ramo de supermercados da cidade de Manhuaçu - MG. In: Anais do II Seminário Científico da FACIG; 2016 nov 16-18; Manhuaçu, Minas Gerais. Manhuaçu: FACIG; 2016. P. 1-12.

6 DATASUS [homepage na internet]. Sistema de Gerenciamento da Tabela de Procedimentos, Medicamentos e OPM do SUS [acesso em 09 ago 2017]. Disponível em: http://sigtap.datasus.gov.br/ tabela-unificada/app/sec/inicio.jsp

7 Banco Central do Brasil [homepage na internet]. Calculadora do Cidadão [acesso em 05 de set de 2017]. Disponível em: https:// www3.bcb.gov.br

8 Brasil. Lei nº 11709 de 19 de junho de 2008. Código Civil. Diário Oficial da União 1 mar 2008

9 Brasil. Decreto n 8948 de 29 de dezembro de 2016. Regulamenta a lei $n^{\circ} 13.152$, de 29 de julho de 2015 , que dispõe sobre o valor do salário mínimo e a sua política de valorização de longo prazo. Diário Oficial da União 2016;30:12

10 Perri JL, Zwolak RM, Goodney PP, Rutherford GA, Powell RJ. Reimbursement in hospital-based vascular surgery: Physician and practice perspective. J Vasc Surg 2017;66(01):317-322. Doi: $10.1016 /$ j.jvs.2017.03.417

11 Instituto Brasileiro de Geografia e Estatística [homepage na internet]. Censo Brasileiro 2007. [acesso em 20 de outubro de 2017]. Disponível em: http:www.ibge.gov.br

12 Instituto Brasileiro de Geografia e Estatística [homepage na internet]. Projeção da população do Brasil e das Unidades da Federação [acesso em 16 de dezembro de 2017]. Disponível em: http:www.ibge.gov.br 